\title{
How Long does it Take to Examine Young Children with the Caries ICDAS System and how do they Respond?
}

\author{
Stefania Martignon ${ }^{1,2}$, Andrea Cortes 1 , Soledad Isabel Gómez ${ }^{3}$, Gina Alejandra \\ Castiblanco ${ }^{1}$, Ximena Baquero ${ }^{4,5}$, Ana María Franco-Triviño ${ }^{4}$, Juliana Carolina \\ Palacio-Benavides ${ }^{4}$, Luis Fernando Gamboa', Rita S Villena ${ }^{6}$
}

\begin{abstract}
A caries-epidemiological study using the ICDASepi-merged system was conducted in Colombian young children. This study aimed at associating the time needed for the clinical examination of caries and caries risk in 1 to 5-year-old children according to age and caries risk, and to assess behavior and child pain self-perception during examination according to age. After IRB approval and given parents/caregivers' informed consent, seven trained examiners assessed 1 to 5 -year olds in kindergartens under local field conditions. ICDASepi-merged caries experience ( $\mathrm{d}_{\text {epiME }} \mathrm{mf}$ ) was assessed as follows: Initial$d_{\text {epi }}$ (ICDAS 1/2 without air-drying); Moderate- $d_{M}$ (ICDAS 3,4); Extensive- $d_{E}($ ICDAS 5,6) lesions; due-to-caries fillings- $f$ and missing-m surfaces/teeth. Caries risk was assessed with Cariogram ${ }^{\circledR}$. Child's behavior (Frankl-Behavior-Rating-Scale) and self-perceived pain (Visual-Analogue-Scale-of-Faces) during examination were evaluated. Clinical examination time was recorded with a stopwatch. A total of 592 children participated (1-yr.: $n=31$; 2 -yrs.: $n=96 ; 3-y r s .: n=155 ; 4-y r s .: n=209,5$-yrs.: $n=101)$. The $d_{\text {epiME }} m f s$ prevalence was of $79.9 \%$ and the mean $8.4 \pm 10.4$. Most were high-caries-risk children (68.9\%). The majority $(58.9 \%)$ showed $\geq$ positive-behavior and $\leq$ light-pain self-perception (88.4\%). Mean clinical examination time was around 3.5 minutes ( $216.9 \pm 133.9$ seconds). For 5 -yr. olds it corresponded to 4 minutes ( $240.4 \pm 145.0$ seconds) vs. 2 minutes ( $122.8 \pm 80.1$ seconds) for 1 -yr. olds (Kruskal-Wallis; $p=0.00$ ). For high- and low-caries risk children it was around 4.3 minutes (255.7 \pm 118.5 seconds) and 3.3 minutes (201.3 \pm 129.4 seconds), respectively (ANOVA; $p=0.01$ ). This study demonstrates using the ICDAS system in young children is feasible, taking less than 4 minutes for the clinical examination without children behavior/ pain self-perception issues.
\end{abstract}

'UNICA - Caries Research Unit, Research Vice-rectory, El Bosque University, Bogotá, Colombia ${ }^{2}$ Dental Innovation and Translation Centre, King's College Dental Institute, London, UK ${ }^{3} \mathrm{ClO}$ - Centro de Investigaciones Odontológicas, Javeriana University, Bogotá, Colombia ${ }^{4}$ Dental Faculty, Javeriana University, Bogotá, Colombia ${ }^{5}$ Paediatric Dentistry Specialization Program, Dental Faculty, El Bosque University, Bogotá, Colombia ${ }^{6}$ San Martín de Porres University, USMP - Lima, Peru

Correspondence: Stefania Martignon, Av. Cra 9 No. 131 A 02, 20 Piso, 110121 Bogotá, Colombia. Tel: +57-1-648-9032. e-mail: martignonstefania@unbosque.edu.co

Key Word: Dental caries, diagnosis, epidemiology, children, time.

\section{Introduction}

The current understanding of the caries process and the possibility of controlling the disease at an earlier stage, have come along with the development of registration systems (1-2). Such systems allow for the assessment of the disease, starting with the visual earlier stages, opening a new area for epidemiology and the planning of preventive strategies (2-8). The ICDAS system (International Caries Detection and Assessment System) is compatible with the conventional WHO criteria (dmf/DMF) (2-5,7-9) (Table 1). The ICDASepimerged system uses a simpler manner of caries registering merging the six ICDAS caries codes into three severity stages, namely Initial (ICDAS $1 \& 2$ ), Moderate (ICDAS $3 \& 4$ ), and Extensive (ICDAS $5 \& 6$ ). With the use of this system the caries experience (including missing and filled surfaces/ teeth) can be expressed conventionally (Conventional dmf/ DMF), where the component " $d$ " includes ICDAS Moderate and Extensive caries stages $\left(\mathrm{d}_{\mathrm{ME}} \mathrm{mf}\right)$ and with the ICDASmerged system, including ICDAS Initial caries stages ( $\mathrm{d}_{\text {IME }} \mathrm{mf}$ ) $(2-5,7)$. When the system is used in an epidemiological field with no availability of compressed air, it is adapted as ICDASepi $\left(d_{\text {epimemf }}\right)$, where the Initial ICDASepi caries lesions include those clinically visible without air-drying (all ICDAS codes 2 white and brown, and ICDAS codes 1 brown) $(1-2,4)$.

Despite the advantages of a clinical examination including different stages of caries lesions and the possibility of planning more inclusive preventive measures, it is generally perceived that for epidemiological studies the use of such a system can be time consuming and cause discomfort in children. Nevertheless, there is no evidence of the actual time spent at examination using the ICDAS system, nor reports on the discomfort/pain perceived by the examined children.

In Colombia an epidemiological caries study was planned in toddler and pre-school children as part of an IADR Latin American Region project (IADR-LAR RDP - Regional Development Program, 2009). The competing interest of this paper is within the clinical and epidemiological assessment of caries lesions with a registration system that includes initial lesions - the ICDAS system, contributing, on one side, to have information about examination time and 
discomfort aspects for better planning of epidemiological studies, and to contribute gathering in Latin American countries epidemiological data that allows to understand better the behavior of dental caries in our child population, as well as to plan promotion and prevention programs. This study aimed at looking for the association between the period of time needed for the clinical examination of caries (ICDASepi-merged system) and caries risk in 1 to 5 -year-old children according to their age and their caries risk classification. A secondary objective of our study was to assess behavior and child pain self-perception during examination by age.

\section{Material and Methods}

This study was approved by the Ethics Committee in Javeriana University, Bogota, Colombia (PUJ 009-2011). This research has been conducted in full accordance with the World Medical Association Declaration of Helsinki.

\section{Children Participation}

The sample size was determined by the IADR-LAR PDR project as a convenience sample of 5001 to 5 year-old children per site. Six low-socioeconomic status kindergartens in Bogotá were invited to participate through a letter of invitation and meetings with the schools' principals, and 5 agreed to participate. Parents/caregivers were sent information about the study in writing and form of intention to participate (2012). Those who showed interest in the study and provided contact information through the intention form were contacted in writing to provide further information, the informed consent form and a form regarding the child's medical conditions. Parents/ caregivers were given a week to go through the consent form and their questions were answered by phone. Children with systemic conditions/mental or physical disabilities reported by the parents were excluded from participation. Parents/caregivers who agreed to participate and whose children did not meet the exclusion criteria returned the signed consent forms to the schools. Included children were then sent a short questionnaire regarding systemic conditions/mental or physical disabilities, use of fluoridated toothpaste and diet habits. Parents filled the questionnaire and returned it to the school.

\section{Training in Caries Examination with ICDAS Criteria}

The training of examiners for this study is described extensively by Martignon et al. (10). Briefly, a three-day training course was conducted by an expert trained member of the ICDAS/ICCMS ${ }^{\text {TM }}$ group (SM) (2). The course included a theory session with images and natural extracted preselected teeth, two clinical exercises with patients, and discussion sessions.

\section{Clinical Examination}

Trained dental students brushed children's teeth with a pea-size amount of fluoridated toothpaste (1100 ppm).

Seven examiners conducted clinical examinations in the children during morning hours, in portable dental units, using headlights, mouth mirrors, ball-ended probes and cotton rolls. The caries visual assessment was conducted by means of the ICDASepi-merged system ( $d_{\text {epime }}$ ) (7) (Table 1). Filled surfaces (f) and due-to-caries missing teeth $(\mathrm{m})$ were also recorded.

Individual caries risk was assessed with the Cariogram ${ }^{\circledR}$ software (11), excluding microbiological and buffer capacity tests. In the software, the "country risk" category's input was set as high based on caries experience figures of the Third National Oral Health Survey (12) and the "group" category was set as normal. "Caries experience", "oral hygiene" and "salivary flow" variables were measured clinically. The conventional mean caries experience $\left(\mathrm{d}_{\mathrm{ME}} \mathrm{mft}\right)$ was compared with that of corresponding age from the Third National Oral Health Survey (12). "Oral hygiene" was calculated with the assessment of plaque before

Table 1. ICDASepi-merged caries categories, and ICDAS and Conventional caries experience

\begin{tabular}{|c|c|c|c|c|}
\hline \multicolumn{3}{|c|}{ ICDASepi-merged Caries categories } & \multicolumn{2}{|c|}{ Correspondent Caries Experience } \\
\hline Score & & ition & ICDAS (ICDASepi-merged) & Conventiona \\
\hline S & $\begin{array}{l}\text { Sound } \\
\text { (ICDAS 0) }\end{array}$ & No evidence of visible caries & $\begin{array}{l}\text { No caries experience: } \\
\mathrm{d}_{\text {epiME }} \mathrm{mfs}=0\end{array}$ & No caries \\
\hline$d_{\text {epi }}$ & $\begin{array}{l}\text { Initial-epi stage caries } \\
\text { (ICDAS-epi 1,2) }\end{array}$ & $\begin{array}{l}\text { First/distinct visual change } \\
\text { in enamel observed with } \\
\text { no available air-drying }\end{array}$ & & $\begin{array}{l}\text { experience: } \\
\mathrm{d}_{\mathrm{ME}} \mathrm{mfs}=0\end{array}$ \\
\hline$d_{M}$ & $\begin{array}{l}\text { Moderate stage caries } \\
\text { (ICDAS 3,4) }\end{array}$ & $\begin{array}{l}\text { Localized enamel breakdown or } \\
\text { dentine-underlying shadow }\end{array}$ & $\mathrm{d}_{\text {epiME }} \mathrm{mfs} \geq 1$ & \\
\hline$d_{E}$ & $\begin{array}{l}\text { Extensive stage caries } \\
\text { (ICDAS 5,6) }\end{array}$ & $\begin{array}{l}\text { A distinct cavity in opaque } \\
\text { or discolored enamel } \\
\text { with visible dentine }\end{array}$ & & $\mathrm{d}_{\mathrm{ME}} \mathrm{mfs} \geq 1$ \\
\hline
\end{tabular}


toothbrushing with the modified Silness \& Löe Index median (0: no plaque; 1 : thin plaque; 2 : thick plaque) and for "salivary flow" a surrogate test was used as previously reported (13). For the "Fluoride program" variable, the use of fluoride toothpaste and the national-wide systemic salt fluoridation program in Colombia (14) were taken into account. The Cariogram software classifies subjects according to their risk as: very low, low, moderate, high and very high. For this study children's caries risk was classified into three options: high risk (combining high and very high classifications), moderate, and low (combining low and very low classifications).

Time used for the clinical examination was measured in seconds with a stopwatch and registered by an external examiner present during the clinical assessment.

A trained paediatric-dentistry resident assessed the child's behavior during the clinical examination by means of the Frankl Behavior Rating Scale (15) (very positive, positive, negative, or very negative). After the examination, in children 3 years and older, pain perception was selfreported by each girl and boy by means of the Visual Analogue Scale of Faces (16) (no/very light pain, light pain, moderate pain, intense pain, unbearable pain).

\section{Statistical Analysis}

To calculate the inter- and intra-examiner ICDAS caries visual criteria reproducibility of the training of examiners Weighted Kappa values were calculated during the calibration process.

All data were first registered by hand in paper forms at the kindergartens and later entered to an Excel ${ }^{\circledR}$ sheet by two trained research assistants. Afterwards, 10\% of data was verified. Descriptive statistics (mean and standard deviations) were calculated for the variables time (in seconds).

Children were divided in five subgroups by age as follows: 1 year (12-23 months); 2 years (24-35 months); 3 years (36-47 months); 4 years (48-59 months), and 5 years (60-71 months).

The examination time (in seconds) was calculated and reported by age group (mean and standard deviations).

Caries experience was calculated for each age group. Variables included prevalence of conventional and ICDASepi-merged caries experience $\left(d_{M E} m f\right.$ and $d_{\text {epiME }} m f$, respectively) and mean of teeth/surfaces with conventional and ICDASepi-merged caries experience $\left(\mathrm{d}_{\mathrm{ME}} \mathrm{mft} / \mathrm{s}\right.$ and $\mathrm{d}_{\text {epiME }} \mathrm{mft} / \mathrm{s}$, respectively) (Table 1). Furthermore, proportions of children's caries risk, behavior and pain perception were calculated by age group.

Differences of the time used for the clinical examination (ICDAS and caries risk) were explored among age groups and among caries risk classification. The behavior and pain self-perception assessments were associated with age.

Data analyses were carried out using STATA ${ }^{\circledR}$ statistical software (Version $14 \mathrm{SE}$; Stata Corporation, College Station, Texas). The significance level was set at $p<0.05$. The Shapiro Wilk test was used to determine whether or not the distribution of data was normal.

To determine if there was any association between age and caries risk, examination time, behavior and pain perception, and between caries risk and examination time, in those variables with normal distribution One-way ANOVA was used and in variables with non-normal distribution Kruskal-Wallis test was used. When the expected values in each test were significant the U Mann-Whitney test was used to establish the related variable; otherwise, the t-test was used.

\section{Results}

The inter- and intra-examiner reproducibility of the examiners in the ICDAS caries visual criteria were Weighted Kappa values between $0.70-0.77$ and 0.70 0.85 , respectively.

A total of 5921 to 5-year-old children were examined (325 boys and 267 girls) in low socio-economic status kindergartens. The distribution of the sample by age was as follows: 1 -year-olds: $n=31$; 2 -year-olds: $n=96$; 3 -yearolds: $n=155 ; 4$-year-olds: $n=209$, and 5-year-olds: $n=101$ (Table 2).

\section{Caries Experience}

The prevalence of ICDASepi-merged caries experience $\left(d_{\text {epiME }} m f\right)$ was $79.9 \%$ (conventional caries experience, $d_{M E} m f: 51.7 \%$ ). Correspondent prevalence of ICDASepimerged and Conventional caries experience figures according to age group were: 1-year-olds: $29.0 \%$ and 6.4\%; 2-year-olds: $79.2 \%$ and $39.6 \%$; 3 -year-olds: $81.3 \%$ and $44.5 \%$; 4-year-olds: $85.6 \%$ and $58.4 \%$, and 5 -yearolds: $82.2 \%$ and $74.3 \%$, respectively.

The mean number of surfaces with ICDASepi-merged caries experience $\left(\mathrm{d}_{\text {epiME }} \mathrm{mfs}\right)$ was $8.4 \pm 10.4\left(\mathrm{~d}_{\text {epiME }} \mathrm{S}\right.$ : 7.6 \pm 4.5 ; ms: $0.2 \pm 0.9$; fs: $0.6 \pm 1.9$ ). Correspondent conventional caries experience mean at the tooth level $\left(\mathrm{d}_{\mathrm{ME}} \mathrm{mft}\right)$ was $2.1 \pm 2.3\left(\mathrm{~d}_{\mathrm{ME}} \mathrm{t}: 1.5 \pm 2.0 ; \mathrm{mt}: 0.2 \pm 0.8 ; \mathrm{ft}\right.$ : $0.4 \pm 0.5)$ and at the surface level $\left(\mathrm{d}_{\mathrm{ME}} \mathrm{mfs}\right) 3.9 \pm 6.6$. Figure 1 shows ICDASepi-merged and Conventional caries experience increment per age group. There was a significant ICDASepi-merged and Conventional caries experience difference between the 1-year old age group and the other age groups (Kruskal-Wallis test; $p=0.01$ ), with the 1-year old group having significantly lower mean number of surfaces with ICDASepi-merged and Conventional caries experience than the rest (U MannWhitney test; $p<0.005$ ). 


\section{Caries Risk}

Table 2 shows that most children were at high caries risk (68.9\%). While in the 1, 2, 3-, and 4-year old groups over $64 \%$ of children were classified as high caries risk, in the 5-year-old group this corresponded to only around half of children (53.5\%) (Kruskal-Wallis test; $p=0.01$ ). The 5-year-old group had a significantly lower frequency of high-caries risk children than all other age groups (U Mann-Whitney test; $p<0.05$ ).

\section{Examination Time}

The mean clinical examination time per child was 3 min and $37 \mathrm{~s}(216.9 \pm 133.9$ seconds). When discriminating by age, the 5- and the 4-year-old groups showed the highest examination mean time of around $4 \mathrm{~min}$, followed by the 2-year-old group with $3 \mathrm{~min}$ and $44 \mathrm{~s}$ (Table 2). The 1 -year-old group showed the shortest clinical examination time (2 min and $3 \mathrm{~s}$ ) (Kruskal-Wallis test; $p=0.00$ ), which was significantly lower in comparison to the 5- (U MannWhitney test; $p=0.000$ ) and the 4-year-old (U MannWhitney test; $p=0.002$ ) groups.

With regards to caries risk and examination time there was a linear correlation with a lower mean examination time for the low-risk children of $3 \mathrm{~min}$ and $21 \mathrm{~s}(201.3 \pm 129.4 \mathrm{~s})$, followed by $4 \mathrm{~min}$ and $7 \mathrm{~s}$ for the moderate-risk children $(246.9 \pm 157.1 \mathrm{~s})$, and $4 \mathrm{~min}$ and $16 \mathrm{~s}$ for the high-risk children (255.7 $\pm 118.5 \mathrm{~s})($ ANOVA; $p=0.01)$.

\section{Behavior}

Most children's behavior during the clinical examination was classified as definitively positive/positive (58.9\%). While almost all 5-year-old children (89.1\%) showed definitely positive/positive behavior during examination, this decreased to less than half ( $41.9 \%)$ in the 1-year-olds (Table 3). The latter showed higher definitively negative behavior during the clinical examination than other groups (Kruskal-Wallis test; $p<0.05$ ).

\section{Pain self-Perception}

Pain self-perception during the clinical examination was assessed in 456 children ( 3 to 5 -year-olds). In the majority of the children pain self-perception was found to be very light/light (88.4\%). As with behavior assessment almost all 5 -year-olds (95\%) reported very light/light pain, decreasing

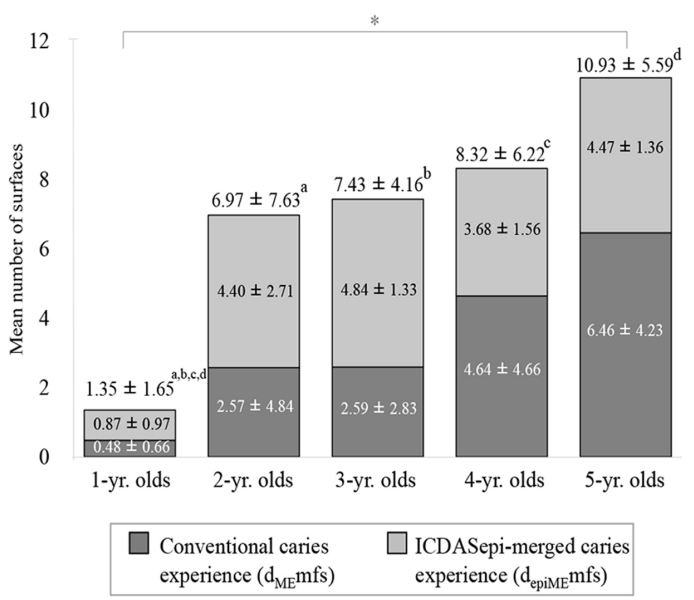

Figure 1. ICDASepi-merged and Conventional mean caries experience by age group. "Statistically significant difference in Conventional and ICDASepi-merged caries experience between 1-year olds and other groups (Kruskal-Wallis test; $\mathrm{p}=0.01$ ). Statistically significantly lower Conventional and ICDASepi-merged caries experience (U Mann-Whitney test) between: a 1 - and 2-year-olds ( $\mathrm{p}=0.004)$; ${ }^{\mathrm{b}} 1$ and 3-year-olds ( $\mathrm{p}=0.014)$; ${ }^{\mathrm{c}} 1$ - and 4-year olds $(\mathrm{p}=0.036)$; ${ }^{\mathrm{d}} 1$ - and 5 -year-olds $(\mathrm{p}=0.012)$.

Table 2. Caries risk and mean examination time according to age group

\begin{tabular}{|c|c|c|c|c|c|c|c|c|}
\hline \multirow{3}{*}{ Age group } & \multicolumn{6}{|c|}{ Caries risk } & \multicolumn{2}{|c|}{ Examination time (s) } \\
\hline & \multicolumn{2}{|c|}{ High } & \multicolumn{2}{|c|}{ Moderate } & \multicolumn{2}{|c|}{ Low } & \multirow{2}{*}{ Mean } & \multirow{2}{*}{$\pm \mathrm{SD}$} \\
\hline & $\mathrm{n}$ & $\%$ & $\mathrm{n}$ & $\%$ & $\mathrm{n}$ & $\%$ & & \\
\hline 1 -yr-olds $(\mathrm{n}=31)$ & 20 & $64.5^{\mathrm{b}, \mathrm{c}}$ & 6 & 19.4 & 5 & 16.1 & 122.81 & $80.13^{\mathrm{f}, \mathrm{h}, \mathrm{i}}$ \\
\hline 2 -yr-olds $(\mathrm{n}=96)$ & 70 & $72.9^{\mathrm{b}, \mathrm{d}}$ & 11 & 11.5 & 15 & 15.6 & 224.18 & $145.97^{\mathrm{g}}$ \\
\hline 3-yr-olds $(n=155)$ & 119 & $76.8^{\mathrm{b}, \mathrm{e}}$ & 21 & 13.5 & 15 & 9.7 & 185.79 & $103.75^{g}$ \\
\hline 4-yr-olds (n= 209) & 145 & $69.4^{\mathrm{b}, \mathrm{e}}$ & 32 & 15.3 & 32 & 15.3 & 239.47 & $139.32^{\mathrm{g}, \mathrm{i}}$ \\
\hline 5-yr-olds (n= 101) & 54 & $53.5^{\mathrm{a}, \mathrm{c}, \mathrm{d}, \mathrm{e}}$ & 16 & 15.8 & 31 & 30.7 & 240.45 & $145.06^{\mathrm{g}, \mathrm{h}}$ \\
\hline Total $(n=592)$ & 408 & 68.9 & 86 & 14.5 & 98 & 16.6 & 216.99 & 133.98 \\
\hline
\end{tabular}

a,b Statistically significant difference in high caries risk frequency between 5 -year-olds and other groups (Kruskal-Wallis test; $p=0.01$ ). Statistically significantly lower caries risk frequency (U Mann-Whitney test) between: ${ }^{{ }^{5}}$ - and 1-year-olds ( $\left.\mathrm{p}=0.01\right)$; ${ }^{\mathrm{d}} 5$ - and 2 -year olds ( $\mathrm{p}=0.032$ ); ${ }^{\mathrm{e}} 5$ - and 3 -year olds $(\mathrm{p}=0.000)$; ${ }^{\mathrm{f}} 5$ - and 4-year-olds $(\mathrm{p}=0.003)$. f,g Statistically significant difference in examination time between 1-year olds and other groups (Kruskal-Wallis test; $\mathrm{p}=0.00$ ). Statistically significantly lower examination time (U Mann-Whitney test) between: ${ }^{\mathrm{h}} 1$ - and 5 -year olds $(\mathrm{p}=0.000)$, and ${ }^{\mathrm{i}} 1$ - and 4 -year-olds $(\mathrm{p}=0.002)$. 
in the 3-year-olds to $81.2 \%$ without statistical association (Kruskal-Wallis test; $p>0.05$ ) (Table 4).

\section{Discussion}

This study shows that the examination time for assessing caries with the ICDAS system in toddler and pre-school children with a high caries experience was less than 4 $\min (216.99 \pm 133.98 \mathrm{~s})$. In this study the examination time also included the assessment of intra-oral risk factors to calculate the caries risk and thus the solely caries examination would be even below the figures given.

Even though the examination time might be slightly longer than when using the WHO criteria these data represent feasibility to use the ICDAS criteria for the assessment of caries under epidemiological conditions (9). The advantage of using a registration system that allows for the estimation of the burden of initial caries lesions together with consequent planning of preventive strategies and efforts to control the progression of dental caries $(3-5,17)$ seeking to reduce inequalities $(18)$ has been

Table 3. Distribution of children by age group and Frankl Behavior Rating Scale during the clinical examination.

\begin{tabular}{|c|c|c|c|c|}
\hline Age group & $\begin{array}{l}\text { Definitively } \\
\text { positive (\%) }\end{array}$ & $\begin{array}{c}\text { Positive } \\
(\%)\end{array}$ & $\begin{array}{c}\text { Negative } \\
(\%)\end{array}$ & $\begin{array}{l}\text { Definitively } \\
\text { negative (\%) }\end{array}$ \\
\hline $\begin{array}{l}1 \text {-yr-olds } \\
(\mathrm{n}=31)\end{array}$ & 22.6 & 19.3 & 16.1 & $41.9^{\mathrm{a}}$ \\
\hline $\begin{array}{l}\text { 2-yr-olds } \\
(\mathrm{n}=96)\end{array}$ & 37.5 & 7.3 & 38.5 & $16.6^{\mathrm{a}}$ \\
\hline $\begin{array}{l}\text { 3-yr-olds } \\
(\mathrm{n}=155)\end{array}$ & 45.8 & 2.6 & 45.2 & $6.4^{\mathrm{a}}$ \\
\hline $\begin{array}{l}\text { 4-yr-olds } \\
(n=209)\end{array}$ & 60.8 & 0.5 & 37.3 & $1.4^{\mathrm{a}}$ \\
\hline $\begin{array}{l}\text { 5-yr-olds } \\
(\mathrm{n}=101)\end{array}$ & 88.1 & 1.0 & 10.9 & $0^{\mathrm{a}}$ \\
\hline $\begin{array}{l}\text { Total } \\
(\mathrm{n}=592)\end{array}$ & 55.7 & 3.2 & 33.9 & 7.1 \\
\hline
\end{tabular}

a Statistically significant difference in children with definitely negative behavior between 1-year-olds and other groups (Kruskal-Wallis test; $\mathrm{p}<0.05$ ).

Table 4. Distribution of 3 to 5-year-old children by age group and pain selfperception (Visual Analogue Scale of Faces) during the examination time.

\begin{tabular}{lccccc}
\hline Age group & $\begin{array}{c}\text { Very light } \\
\text { pain (\%) }\end{array}$ & $\begin{array}{c}\text { Light } \\
\text { pain (\%) }\end{array}$ & $\begin{array}{c}\text { Moderate } \\
\text { pain (\%) }\end{array}$ & $\begin{array}{c}\text { Intense } \\
\text { pain (\%) }\end{array}$ & $\begin{array}{c}\text { Unbearable } \\
\text { pain (\%) }\end{array}$ \\
\hline $\begin{array}{l}\text { 3-yr-olds } \\
\text { (n=155) }\end{array}$ & 54.2 & 27.1 & 9.7 & 7.1 & 1.9 \\
$\begin{array}{l}4-y \text {-olds } \\
(\mathrm{n}=209)\end{array}$ & 76.6 & 13.9 & 2.9 & 4.8 & 1.9 \\
$\begin{array}{l}5 \text {-yr-olds } \\
(\mathrm{n}=101)\end{array}$ & 87.1 & 7.9 & 3.0 & 2.0 & 0 \\
$\begin{array}{l}\text { Total } \\
(\mathrm{n}=465)\end{array}$ & 71.4 & 17.0 & 5.2 & 5.0 & 1.5 \\
\hline
\end{tabular}

widely reported and this has led to recommending $(9,18)$ and using such a system $(6-8,19-22)$ for epidemiological studies, some at a national level.

Figures in the present study were in accordance with results from studies carried out in young children using the Nyvad criteria to assess caries, where they reported a mean examination time of $203.26 \pm 136.17$ seconds in 36 to 50 -month-olds and $224.17 \pm 134.75 \mathrm{~s}$ in $51-70$-montholds (23).

To the knowledge of the authors children's behavior and self-pain perception during the clinical examination using a caries registration system that includes initial lesions as ICDAS have not been yet reported. Regarding behavior, most children presented with a positive to very positive behavior during the examination (58.9\%). As expected, an increased percentage of children showed positive to very positive behavior with age increment (55\% in 1-3 years old vs. $75 \%$ in $4-5$ years old). Definitely negative behavior was only observed in $7 \%$ of children.

The Frankl Behavior Rating Scale (15) assesses cooperation, motivation, movement of extremities, conduct/behavior, and verbal communication. In this study, while the behavior was measured during the clinical examination, it is important to take into account that children had also gone through some previous procedures, as lining up and waiting to be examined, plus plaque assessment, and tooth-brushing, which would influence the behavior at the caries assessment. Nevertheless, in this study the children's behavior did not represent loosing of any children. It might however increase the possibility of diagnostic errors as Novaes et al. (24) reported regarding patient discomfort and a higher number of false positive results with visual inspection of approximal surfaces after temporary separation with orthodontic elastic bands. In this study only visual inspection was conducted.

Regarding the self-perception of pain, this was only assessed on 3 years old children and over. Pain intensity was self-reported by the children as being very light to light in almost all children (88\%). Again age influenced pain self-perception, with a higher percentage of 3 -year-olds reporting moderate to unbearable pain $(9 \%)$, followed by 4 -year-olds ( $7 \%$ ) and only $2 \%$ of 5-year-olds.

In a study assessing the efficacy of sealing Distal surfaces of first primary molars with initial caries lesions in 4 to 6-year-olds, children's behavior and pain perception was assessed with same scales, both during placement of orthodontic elastic bands between molars for diagnosis purposes and during the sealing procedure. More than $95 \%$ and $91 \%$ of children presented with positive to very positive behavior and over 89\% and 89\% children reported 
light to very light pain in both procedures, respectively (25).

The overall positive behavior and pain perception results of this study could be related to the fact that the ICDAS caries assessment, coinciding with the conventional caries assessment, are non-surgical procedures and examination time was kept to the minimum possible. In very young children cooperation issues occur as also reported in a study assessing caries with the ICDAS system in South Indian 0 to 3 year old children (21).

Data from the present study showed a high prevalence of conventional caries experience $\left(d_{\mathrm{ME}} \mathrm{mf}\right)(51.7 \%)$, which increased when initial caries lesions $\left(\mathrm{d}_{\text {epime }} \mathrm{mf}\right)$ were included $(79.9 \%)$. The mean number of surfaces with conventional $\left(\mathrm{d}_{\mathrm{ME}} \mathrm{mfs}\right)$ and ICDASepi-merged caries experience $\left(\mathrm{d}_{\text {epiME }} \mathrm{mfs}\right)$ were also considered high $(3.86 \pm 6.61$ and $8.41 \pm 10.46$, respectively), corresponding to a situation where the 2000-year oral health WHO goals for children have not been yet met (26), more taking into account that these data are considering estimates combining children from 1 to 5 years of age. Correspondent prevalence of and mean number of teeth with conventional and ICDAS-epi caries experience in Colombia reported in the IV National Oral Health Study (20) were in 3-year-olds 47\% and 1.8, and $83 \%$ and 5.6, respectively, and in 5-year-olds $62 \%$ and 2.8 , and $89 \% 6.7$, respectively. Even though the National Oral Health Study doesn't show figures at the surface level and despite the fact that no standard deviations are shown within the means, the data presents with the same trend and reflects inequalities (18).

Similar data were recently reported in a study conducted in young children in Bogotá, showing a prevalence of conventional caries experience of $59 \%$ and $66 \%$ at the age of 4- and 6 years, respectively, increasing to $88 \%$ and $89 \%$ when initial caries lesions (ICDAS) were included (7).

Finally, the clinical examination time per child was significantly higher in high/very high caries risk children (4 min and $16 \mathrm{~s}$ ) in comparison to very low/low caries risk children ( 3 min and $21 \mathrm{~s}$ ) (ANOVA test; $p=0.01$ ), and slightly higher in the 5 -year-olds ( 4 min vs. an overall mean of 3 min and 37 s) (Kruskal-Wallis test; $p>0.05$ ).

The fact that the sample in this study was not randomized could be a limitation. Nevertheless, the child population was similar to same age groups assessed in wider epidemiological studies in the same city and country in terms of prevalence of caries experience and mean number of teeth with caries experience, both when considered conventionally and with the inclusion of initial caries lesions (ICDAS) $(7,20)$. In addition, the assessment of caries risk allows defining important characteristics of the population, and this has been conducted in this study.

Within the high caries experience of this child population the information is of use for planning epidemiological studies in young children including the assessment of initial caries lesions.

In conclusion, it takes around $3.5 \mathrm{~min}$ to examine 1 to 5 -year-old children. Overall behavior was positive to definitively positive and pain perception was light to very light. The higher the caries risk and the older the child is, the longer the time required to examine children. Thus, examination with ICDAS is a convenient system to use in children from the first year of age. We recommend taking into account age and caries risk as factors influencing time of examination, for the planning of future studies using the ICDAS system.

\section{Resumo}

Um estudo epidemiológico de cárie usando o sistema ICDAS foi realizado em crianças pequenas colombianas. 0 objetivo deste estudo foi associar o tempo necessário para o exame clínico da cárie e o risco de cárie em crianças de 1 a 5 anos de acordo com a idade e o risco de cárie e avaliar a autopercepção do comportamento e da dor na criança durante 0 exame, de acordo com a idade. Após a aprovação do comitê de ética e do consentimento informado dos pais/responsáveis, sete examinadores treinados avaliaram crianças de 1 a 5 anos em creches em condições locais de campo. A experiência de cárie do ICDAS ( $\mathrm{d}_{\text {epime }} \mathrm{mf}$ ) foi avaliada da seguinte forma: Epi-depi inicial (ICDAS 1/2 sem secagem ao ar); Moderado$d_{M}\left(\right.$ ICDAS 3,4); lesões extensas de $d_{E}($ ICDAS 5,6); restaurações devido a cárie - $f$ e superfícies/dentes ausentes-m. 0 risco de cárie foi avaliado com Cariogram ${ }^{\circledR} .0$ comportamento de crianças (Frankl-Behavior-Rating-Scale) e a autopercepção de dor (Escala Visual-Analógica-de-Rostos) durante 0 exame foram avaliados. 0 tempo de exame clínico foi registrado com um cronômetro. 592 crianças participaram (1 ano: $n=31 ; 2$ anos: $n=96 ; 3$ anos: $n=155 ; 4$ anos: $n=209,5$ anos: $n=101$ ). A prevalência do $d_{\text {epimE }} m f s$ foi de $79,9 \%$ e a média de $8,4 \pm 10,4$. A maioria era de crianças com alto risco de cárie $(68,9 \%)$. A maioria $(58,9 \%)$ apresentou $\geq$ comportamento positivo e $\leq$ autopercepção de dor leve $(88,4 \%)$. 0 tempo médio de exame clínico foi em torno de 3,5 min $(216,9 \pm 133,9 \mathrm{~s})$. Para crianças de 5 anos, correspondeu a $4 \min (240,4 \pm 145,0 \mathrm{~s})$ vs. $2 \min (122,8 \pm 80,1 \mathrm{~s})$ para crianças de 1 ano de idade (Kruskal-Wallis; $p=0,00$ ). Para crianças com alto e baixo risco de cárie, foi em torno de $4,3 \min (255,7 \pm 118,5 \mathrm{~s})$ e 3,3 $\min (201,3 \pm 129,4 s)$, respectivamente (ANOVA; $p=0,01)$. Este estudo demonstra que a utilização do sistema ICDAS em crianças pequenas é viável, levando menos de 4 min para o exame clínico sem problemas de autopercepção de comportamento/ dor em crianças.

\section{Acknowledgements}

The authors want to thank the children and kindergartens for their invaluable help and the Regional Development Program (RDP) IADRLAR for partially supporting the study. Professor Chris Deery, University of Sheffield, UK; Professor Gail Douglas, University of Leeds, UK; and Professor Nigel Pitts, King's College London Dental Institute are thanked for their invaluable help with the professional editing for English language.

\section{References}

1. Topping GV, Pitts NB. International Caries Detection and Assessment System Committee. Clinical visual caries detection. Monogr Oral Sci 2009;21:15-41.

2. ICDAS Foundation - International Caries Detection and Assessment System. Available from www.icdas.org. Latest access August 29, 2018.

3. Pitts NB, Zero DT, Marsh PD, Ekstrand K, Weintraub JA, Ramos-Gomez F. Dental caries. Nat Rev Dis Primers 2017;25:17030.

4. Pitts NB, Ekstrand KR, ICDAS Foundation. International Caries Detection and Assessment System (ICDAS) and its International Caries 
Classification and Management System (ICCMS $\left.{ }^{\mathrm{TM}}\right)$ - methods for staging of the caries process and enabling dentists to manage caries. Community Dent Oral Epidemiol 2013;41:41-52.

5. Pitts NB, Ismail Al, Martignon S, Ekstrand K, Douglas GVA, Longbottom C. et al. (2014, December 19). ICCMS ${ }^{\text {TM }}$ Guide for Practitioners and Educators. Zenodo. Available from: http://doi.org/10.5281/ zenodo.853106. Latest access August 29, 2018

6. Agustsdottir $H$, Gudmundsdottir $H$, Eggertsson $H$, Jonsson $\mathrm{SH}$, Gudlaugsson JO, Saemundsson SR. Caries prevalence of permanent teeth: a national survey of children in Iceland using ICDAS. Community Dent Oral Epidemiol 2010;38:299-309.

7. Cortes A, Ekstrand KR, Gamboa LF, González L, Martignon S. Caries status in young Colombian children expressed by the ICCMS ${ }^{\text {Tm }}$ visual/ radiographic combined caries staging system. Acta Odont Scand 2016;75:12-20

8. Calado R, Ferreira CS, Nogueira $P$, Melo P. Caries prevalence and treatment needs in young people in Portugal: the third national study. Community Dent Health 2017;34:107-111.

9. Braga MM, Oliveira LB, Bonini GA, Bönecker M, Mendes FM. Feasibility of the International Caries Detection and Assessment System (ICDASII) in epidemiological surveys and comparability with the standard criteria. Caries Res 2009;43:245-249.

10. Martignon S, Castiblanco GA, Cortés A, Marin-Gallón LM, GómezRamírez SI, Gómez-González OL. Reporte de una metodología de calibración de examinadores en el uso del Sistema Internacional de Detección y Valoración de Caries (ICDAS). Universitas 2015;34:159-171.

11. Bratthall D, Hänsel Petersson G. Cariogram-a multifactorial risk assessment model for a multifactorial disease. Community Dent Oral Epidemiol 2005;33:256-264.

12. Ministerio de Salud - República de Colombia, Centro Nacional de Consultoría - CNC. III Estudio Nacional de Salud Bucal - ENSAB III. Bogotá, Colombia 1999 40-63.

5 13. Martignon S, Ekstrand KR, Ellwood R. Efficacy of sealing proximal early active lesions: an 18-month clinical study evaluated by conventional and subtraction radiography. Caries Res 2006;40:382-388.

14. Ministerio de Salud y Protección Social. Documento técnico perspectiva del uso del flúor vs caries y fluorosis dental en Colombia. (cited 2017 Jun 10) Available from: https://www.minsalud.gov.co/sites/rid/Lists/ BibliotecaDigital/RIDE/NS/PP/ENT/perspectiva-uso-fluor.pdf.
15. FrankI SN, Shiere FR, Fogels HR. Should the parent remain with the child in the dental operatory? J Dent Child 1962;29:150-163.

16. Reis-Barreto EP, Ferreira-Ferreira I, Almeida-Pordeus I. Evaluation of toothache severity in children using a visual analogue scale of faces. Pediatr Dent 2004;26:485-491.

17. Kühnisch J, Ekstrand KR, Pretty I, Twetman S, van Loveren C, Gizani S, et al. Best clinical practice guidance for management of early caries lesions in children and young adults: an EAPD policy document. Eur Arch Paediatr Dent 2016;17:3-12.

18. Pitts N, Amaechi B, Niederman R, Acevedo AM, Vianna R, Ganss C. Global oral health inequalities: dental caries task group-research agenda. Adv Dent Res 2011;23:211-220.

19. EGOHID II. Health Surveillance in Europe, Oral Health Interviews and Clinical Surveys: Guidelines, European Global Oral Health Indicators Development Programme. Lyon, France; 2008:57-88.

20. Ministerio de Salud y Protección Social - República de Colombia. IV Estudio Nacional de Salud Bucal - ENSAB IV Situación en Salud Bucal. Bogotá, Colombia; 2015:36-67.

21. Henry JA, Muthu MS, Saikia A, Asaithambi B, Swaminathan K. Prevalence and pattern of early childhood caries in a rural South Indian population evaluated by ICDAS with suggestions for enhancement of ICDAS software tool. Int J Paediatr Dent 2017;27:191-200.

22. Séllos MC, Soviero VM. Reliability of the Nyvad criteria for caries assessment in primary teeth. Community Dent Oral Epidemiol 2011;119:225-231.

23. Novaes TF, Matos R, Raggio DP, Braga MM, Mendes FM. Children's discomfort in assessments using different methods for approximal caries detection. Braz Oral Res 2012;26:93-99.

24. Martignon S, Tellez M, Santamaria RM, Gomez J, Ekstrand KR. Sealing distal proximal caries lesions in first primary molars: efficacy after 2.5 years. Caries Res 2010;44:562-570

25. WHO - World Health Organization Oral health information systems. Available from: http://www.who.int/oral_health/action/information/ surveillance/en/. Latest access August 19, 2018

Received October 16, 2017 Accepted May 2, 2018 